\title{
SPATIAL VARIABILITY OF SOIL RESISTANCE TO PENETRATION IN NO TILLAGE SYSTEM
}

\author{
Jorge W. Cortez ${ }^{1 *}$, Wéliton P. da S. Matos ${ }^{2}$, Sálvio N. S. Arcoverde ${ }^{2}$, Victor H. Cavassini², \\ Igor Q. M. Valente ${ }^{3}$
}

${ }^{1 *}$ Corresponding author. Universidade Federal da Grande Dourados/ Dourados - MS, Brasil. E-mail: jorge.cortez@yahoo.com.br

\section{KEYWORDS}

soil compaction, agricultural mechanization, geostatistics.

\begin{abstract}
In areas of no tillage system where there is intense traffic of machines and minimal soil mobilization, the periodic monitoring allied on localized soil compaction represent important strategies aiming agricultural sustainability. Thus, the objective of this study was to evaluate the spatial variability of soil resistance to penetration (RP) in no tillage system. Data collection took place in an experimental area of 7.65 ha using a sample grid composed of 40 points. At each point the RP was determined by three replications from which was obtained the mean RP, the maximum RP, and the depth of the maximum RP in the $0-0.40 \mathrm{~m}$ layer. Deformed samples were randomly collected in the area to determine the water content in the soil $(\theta)$. Then the RP data were analyzed using descriptive and geostatistical statistics techniques for spatial variability maps. The RP presents spatial variability detected by means of spherical semivariogram in all soil layers. There was spatial variability in the area with the appearance of intermediate values for RP (2.00$3.00 \mathrm{MPa}$ ) due to no ploughing and continuous traffic of agricultural machines. There were greater reaches and critical levels of compaction on the layers $0.10-0.20$ and 0.20 $0.30 \mathrm{~m}$ where there is predominance of the maximum RP.
\end{abstract}

\section{INTRODUCTION}

The implementation of conservation management systems, such as no tillage system and reduced tillage, brings benefits to the conservation of natural resources, prioritizing the maintenance of vegetal residues on the surface and reducing soil movement. Among the benefits are the reduction of erosion and the increase of microorganism biological activity reflecting positively on soil quality and the profitability of agricultural activity.

In spite of this, the cultivation in no tillage system by not adopting the soil rotation can result in the formation of compacted layers. In addition to the minimum ploughing which is usually carried out only in the sowing line, the intense number of mechanized operations is also responsible for formation of compacted surface layers, especially when there is continuous traffic of machines on inadequate soil water content (Streck et al., 2004) which can affect soil quality and agricultural production (Bergamin et al., 2010a; Bergamin et al., 2010b).

The soil under ideal conditions for root development is homogeneously exploited by the roots plants, and the soil volume is relatively higher than in soils with compaction problems (Valadão et al., 2015). This is due to the fact that certain compaction states cause changes in the soil structure, resulting in increased soil density and soil resistance to penetration, as well as reduction of total porosity and soil macro porosity (Freddi et al., 2007; Bergamin et al., 2010a; Bergamin et al., 2010b; Valadão et al., 2015).

One of the parameters most used to evaluate the intensity of soil compaction is soil resistance to penetration (Oliveira Filho et al., 2015). Since it is a practical and complete parameter, also related to texture, soil density and soil water content, it has been used for the periodic monitoring of soil compaction status and as an indicator in the evaluation of the effects of management systems of the soil on root environment (Bergamin et al., 2010a; Bergamin et al., 2010b; Valadão et al., 2015).

Critical values of soil resistance to penetration may vary from 1.5 MPa to 4.0 MPa (Rosolem et al., 1999); although, in general, values close to $2 \mathrm{MPa}$ are accepted as impediments to root growth. It has also been observed values of soil resistance to penetration critical to root

${ }^{2}$ Universidade Federal da Grande Dourados/ Dourados - MS, Brasil.

${ }^{3}$ Universidade Estadual de Campinas/ Campinas - SP, Brasil.

Received in: 9-19-2017

Accepted in: 8-15-2018 
development in no tillage system from 3.0 to $4.0 \mathrm{MPa}$ (Vaz et al., 2011; Betioli Júnior et al., 2012; Guimarães et al., 2013). However, Marasca et al. (2011) evaluating the spatial variability of soil resistance to penetration in soybean in no tillage system verified values from 2.9 to 4.28 $\mathrm{MPa}$ which were not considered restrictive to crop production.

The analysis of the spatial behavior of the soil physical attributes through geostatistics allows to detect the variability and spatial distribution of the studied attributes and, with this, to evaluate and describe in a detailed way the variability of the soil attributes (Alves et al., 2014) being important in the management and control of crop production factors, as well as in environmental monitoring (Oliveira et al., 2013).
In view of the above, the objective of this study was to evaluate the spatial variability of soil resistance to penetration (RP) in no tillage system.

\section{MATERIAL AND METHODS}

The study was developed at the Experimental Farm of Agricultural Sciences at Federal University of Grande Dourados (UFGD) located in the municipality of Dourados - MS, Brazil between the geographic coordinates of $22^{\circ} 14^{\prime}$ South latitude and $54^{\circ} 59^{\prime}$ West longitude with an average altitude of $434 \mathrm{~m}$. The climate is type AW, according to the classification of Köppen. The soil of the area is a Distroferric Red Latosol, which granulometric composition, according to the classification proposed by the United States Department of Agriculture (USDA) is presented in Table 1.

TABLE 1. Granulometry composition of the Dystrophic Red Latosol at Experimental Farm in UFGD.

\begin{tabular}{cccc}
\hline Layers & Clay & Silte & Sand \\
\hline$(\mathrm{m})$ & & $\mathrm{g} \mathrm{kg}^{-1}$ & \\
$0.00-0.10$ & 597.8 & 217.3 & 184.9 \\
$0.10-0.20$ & 592.6 & 222.4 & 185.0 \\
$0.20-0.30$ & 623.1 & 197.9 & 179.1 \\
$0.30-0.40$ & 628.3 & 202.3 & 169.4 \\
\hline
\end{tabular}

In the experimental area it is cultivated as summer crop soybean (Glycine max) and as winter crop corn (Zea mays) in a system of succession of crops without ploughing in which the no tillage system on the straw has been adopted for more than 20 years. The area has 7.65 ha and was divided into a mesh with 40 sample points, using a navigation system that contoured the area and generated a sample mesh with a difference between points of 0.20 ha (approximately $45 \mathrm{~m}$ between points).

The determination of soil resistance to penetration (RP) was carried out by means of a digital penetrometer, model PenetroLOG ${ }^{\circledR}$ PLG1020, with electronic capability for data acquisition, according to ASAE S 313.3 (ASABE, 2006). The penetrometer is operated manually and depends on the strength of the rod operator; it is an equipment that has a sonar type sensor which indicates the depth and composes the calculation on the speed penetration and, on the other hand, also warns the user if the speed is out of the standard, canceling the measurement. This penetrometer has a CPU that stores the collected data and has a direct interface to computers, besides a display that allows the user to make settings and view the measurements made for penetration (Molin et al., 2012). The speed penetration of the rod was maintained close to $30 \mathrm{~mm} \mathrm{~s}^{-1}$, according to instrumentation of the apparatus. A cone was used with a diameter of $12.83 \mathrm{~mm}$ and a penetration angle of $30^{\circ}$. The resolution of the equipment is $7.7 \mathrm{kPa}$ and the maximum $\mathrm{RP}$ allowed is $7700 \mathrm{kPa}$ (Cunha et al., 2009).

Data on the penetrometer were extracted from the digital memory and analyzed at a maximum depth of 0.40 $\mathrm{m}$. With these data were obtained the mean and maximum stratified values in the layers $0-0.10 ; 0.10-0.20 ; 0.20-0.30$ and $0.30-0.40 \mathrm{~m}$, as well as the mean RP of the evaluated profile, the maximum RP of the profile $0-0.40 \mathrm{~m}$ and the depth of maximum RP.
The determination of RP was carried out at each sampling point where three measurements were made, in the culture interlayer, within a radius of up to $5 \mathrm{~m}$ from the marked point by the navigation system.

Deformed soil samples were collected in the experimental area randomly in the layers $0-0.10$; 0.10-0.20; $0.20-0.30$ and $0.30-0.40 \mathrm{~m}$ for determination of soil water content $(\theta)$ obtained by the thermogravimetric method. The mean data of $\theta$ were used for general characterization of the area in soil layers.

The RP data were analyzed through descriptive statistics, to allow a general visualization of the data behavior, as well as the normality of the data using the Ryan-Joiner test (Coelho et al., 2012). Then, the geostatistics analysis was performed to verify the spatial dependence of RP by the calculation of the semi variance and data adjustment to the semivariogram. The semivariograms were adjusted by the $\mathrm{GS}^{+}$program from which the models were selected based on the best coefficient of determination $\left(r^{2}\right)$ and the smallest sum of squared residual being tested the spherical, exponential, Gaussian, linear models and linear without baseline and pure nugget effect. In the adjusted semivariograms the following parameters were defined: nugget effect $\left(\mathrm{C}_{0}\right)$; baseline $\left(\mathrm{C}_{0}+\mathrm{C} 1\right)$ and range (A) (Marasca et al., 2011; Coelho et al., 2012; Bottega et al., 2013; Oliveira Filho et al., 2015; Nagahama et al., 2016).

Subsequently, interpolation was performed by ordinary kriging, which is an interpolation technique to estimate values on property in non-sampled locations. By means of kriging interpolation, the (two-dimensional) isoline maps were constructed for spatial detailing of the collected data using a $20 \mathrm{~m}$ interpolation grid. 


\section{RESULTS AND DISCUSSION}

The values of soil water content $(\theta)$ in the layers $0.10-0.20 ; 0.20-0.30$ and $0.30-0.40 \mathrm{~m}$ (Table 2) are above the range, according to Bottega et al. (2013), higher than that recommended for mechanized operations. It can be observed that there was an increase from $\theta$ to the layer of $0.20-0.30 \mathrm{~m}$ with higher average variation $(13.0 \%)$ of its surface layer values $(0.00-0.10$ and $0.10-0.20 \mathrm{~m})$ for the layers of $0.20-0.30$ and $0.30-0.40 \mathrm{~m}$.

These results disagree with those found by Bottega et al. (2013) who working on dystroferric Red Latosol under no tillage system verified greater variation of $\theta$ values in the superficial layer, however it should be noted that other factors such as sampling time and organic matter content may influence this variation, as well as RP values.
TABLE 2. Water content in soil $(\theta)$ at the moment of the mechanical resistance of the soil to penetration (RP).

\begin{tabular}{cc}
\hline Layer $(\mathrm{m})$ & Water content in soil $(\%)$ \\
\hline $0.00-0.10$ & 23.37 \\
$0.10-0.20$ & 23.94 \\
$0.20-0.30$ & 27.11 \\
$0.30-0.40$ & 26.50 \\
\hline
\end{tabular}

In the summary of the descriptive statistical analysis for soil resistance to penetration (RP) in the different studied layers (Table 3), there is an increase in RP with depth up to the layer of $0.20-0.30 \mathrm{~m}$, in which we found maximum levels of compaction. Cortez et al. (2014) point out that the lower RP found in the $0.0-0.10 \mathrm{~m}$ layer in relation to the underlying layers can be attributed to the deposition of organic matter that contributes to soil density reduction.

TABLE 3. Descriptive statistics of soil resistance to penetration (kPa).

\begin{tabular}{|c|c|c|c|c|c|c|c|}
\hline \multirow[t]{2}{*}{ Parameters } & \multicolumn{6}{|c|}{ Layers (m) } & \multirow[b]{2}{*}{$\begin{array}{c}\text { Depth of } \\
\text { maximum RP }\end{array}$} \\
\hline & $0-0.10$ & $0.10-0.20$ & $0.20-0.30$ & $0.30-0.40$ & $\begin{array}{l}\text { General } \\
\text { average }\end{array}$ & $\mathrm{RP}$ maximum & \\
\hline & \multicolumn{7}{|c|}{ Average layer value } \\
\hline Average & 1322.6 & 2658.6 & 2668.4 & 2397.4 & 2238.9 & 3526.9 & 21.38 \\
\hline SD & 451.0 & 345.2 & 488.8 & 597.5 & 344.6 & 594.7 & 6.43 \\
\hline Variance & 203400.3 & 119161.7 & 238959.0 & 357037.9 & 118751.0 & 353672.0 & 41.37 \\
\hline $\mathrm{CV}$ & 34.10 & 12.98 & 18.32 & 24.92 & 15.39 & 16.86 & 30.09 \\
\hline Minimum & 598.3 & 2163.7 & 2006.7 & 1594.0 & 1762.3 & 2657.3 & 11.00 \\
\hline Maximum & 2316.7 & 3634.0 & 4209.7 & 4196.0 & 3346.0 & 4856.7 & 36.00 \\
\hline Asymmetry & 0.49 & 0.81 & 1.38 & 1.16 & 1.36 & 0.71 & 0.46 \\
\hline Curtose & -0.65 & 0.19 & 1.79 & 1.35 & 2.10 & -0.38 & -0.19 \\
\hline \multirow[t]{2}{*}{ Prob } & $>0.10$ & 0.05 & $<0.01$ & $<0.01$ & $<0.01$ & 0.03 & $>0.10$ \\
\hline & \multicolumn{7}{|c|}{ Maximum Layer Value } \\
\hline Average & 2637.0 & 3117.5 & 3022.6 & 2725.0 & 2875.5 & -- & -- \\
\hline SD & 764.0 & 449.2 & 495.8 & 647.0 & 427.6 & -- & -- \\
\hline Variance & 583482.0 & 201805.6 & 245785.1 & 419103.0 & 182834.3 & -- & -- \\
\hline $\mathrm{CV}$ & 28.96 & 14.41 & 16.40 & 23.76 & 14.87 & -- & -- \\
\hline Minimum & 1585.0 & 2397.3 & 2190.7 & 1812.0 & 2245.0 & -- & -- \\
\hline Maximum & 4496.0 & 4361.7 & 4539.7 & 4406.0 & 4042.7 & -- & -- \\
\hline Asymmetry & 0.83 & 0.59 & 1.22 & 0.79 & 1.13 & -- & -- \\
\hline Curtose & -0.22 & 0.05 & 1.69 & 0.05 & 1.13 & -- & -- \\
\hline Prob & 0.015 & $>0.10$ & $<0.01$ & 0.05 & $<0.01$ & -- & -- \\
\hline
\end{tabular}

${ }^{*} \mathrm{p} \geq 0.05$ normal, non-significant - symmetric data; $* * \mathrm{p}<0.05$ non - normal, significant - asymmetric data. SD: standard deviation; CV: coefficient of variation; Prob: probability.

In general, the mean RP is low ( $<2.00 \mathrm{MPa})$, in the 0-0.10 $\mathrm{m}$ layer, the intermediate layer (2.00-3.00 MPa) in the other layers, below the critical levels (3.00-4.00 MPa) reported in research projects (Vaz et al., 2011; Betioli Júnior et al., 2012; Guimarães et al., 2013); although, according to Rossolem et al. (1999) restrictive values may range from 1.5 to 4.0 MPa as a function of culture. However, Secco et al. (2009) found that RP values close to $2 \mathrm{MPa}$ are limiting to grain yield in maize in Dystrophic Red Latosol and Dystroferric Red Latosol; while Marasca et al. (2011) observed that critical RP levels in the order of 2.9 to 4.28 MPa in dystroferric Red Latosol did not prove to be limiting to soy production.

Also in Table 3 high amplitude is observed between the minimum and maximum RP values, 598.3 and 4209.7 $\mathrm{kPa}$, in the layers $0-0.10$ and $0.20-0.30 \mathrm{~m}$, respectively, demonstrating that the inadequate traffic possibly influences the variability of the attribute which shows that there are critical points in the area which should receive differentiated management. Despite this large amplitude the coefficient of variation was low with the data following a normal distribution.

When analyzing the maximum value, it is possible to notice that the layers' values $0.10-0.20$ and $0.20-0.30 \mathrm{~m}$ are just above $3 \mathrm{MPa}$, considered critical and limiting for both root development and maize crop production (Freddi et al., 2007). This can be explained by the increased traffic of the mechanized assemblies in the area in question. According to Valadão et al. (2015) there is positive correlation between $\mathrm{RP}$ and intensification of the traffic to the depth of $0.20 \mathrm{~m}$ in no tillage area.

According to Nogueira (2007), coefficient of variation greater than $35 \%$ reveals that the series is heterogeneous and the mean has little meaning; if it is greater than $65 \%$, the series is very heterogeneous and the mean has no meaning, but if it is less than $35 \%$ the series is 
homogeneous and the mean has significance. In this case, this can be used as representative of the series in which it was obtained. Considering these data, the RP in the soil layers presented a homogeneous series (Table 3 ).

It should be noted that the values of standard deviation and variance (Table 3) were higher in the layers $0.20-0.30$ and $0.30-0.40 \mathrm{~m}$, showing that in these layers the variability of compaction degree is higher showing that the compaction effect by machine traffic is reflected in these regions; unlike that found by Bottega et al. (2013) which under similar condition to those on the present study, observed a decrease in these parameters with depth increase; that is, the highest RP values were found in the superficial layer.

The normality test indicated a normal distribution for the analyzed variables, even though this is not an assumption for the application of geostatistics. All variables presented values of asymmetry and kurtosis within the range of -2 and 2 (Table 3 ), which indicates that the data respect a normal distribution (Albiero et al., 2012; Melo et al., 2013; Silva et al., 2013).

From the semivariogram analysis for RP (Table 4) we observed the adjustment of the spherical model for the evaluated layers and for the analysis of the maximum resistances and the occurrence depths of maximum resistances throughout the evaluated area, agreeing with Cortez et al. (2014) when analyzing RP in Yellow Argisol under different intensities of tractor traffic. Similarly, Marasca et al. (2011), Oliveira Filho et al., (2015) and Nagahama et al. (2016) when evaluating spatial variability of RP verified a greater adjustment of the spherical model for soil physical attributes.

TABLE 4. Semivariogram adjusted data and cross-validation for soil resistance to penetration in the studied layers.

\begin{tabular}{|c|c|c|c|c|c|c|c|}
\hline & \multicolumn{4}{|c|}{ Layers (m) } & \multirow[b]{2}{*}{$\begin{array}{l}\text { General } \\
\text { average }\end{array}$} & \multirow[b]{2}{*}{$\begin{array}{l}\text { RP max } \\
\text { profile }\end{array}$} & \multirow[b]{2}{*}{$\begin{array}{l}\text { Depth of the } \\
\text { maximum RP }\end{array}$} \\
\hline & $0.00-0.10$ & $0.10-0.20$ & $0.20-0.30$ & $0.30-0.40$ & & & \\
\hline & \multicolumn{7}{|c|}{ Average layer value } \\
\hline Model & Spherical & Spherical & Spherical & Spherical & Spherical & Spherical & Spherical \\
\hline Co & 0.00 & 0.00 & 0.00 & 0.00 & 0.00 & 0.00 & 0.00 \\
\hline $\mathrm{Co}+\mathrm{C}$ & 260788.98 & 194424.61 & 387278.52 & 551158.09 & 205236 & 528428.7 & 47.39 \\
\hline \multirow[t]{2}{*}{$\mathrm{A}(\mathrm{m})$} & 443.96 & 584.01 & 469.96 & 422.92 & 475.28 & 477.72 & 432.40 \\
\hline & \multicolumn{7}{|c|}{ Maximum Layer Value } \\
\hline Model & Spherical & Spherical & Spherical & Spherical & Spherical & -- & -- \\
\hline Co & 0.00 & 0.00 & 0.00 & 0.00 & 0.00 & -- & -- \\
\hline $\mathrm{Co}+\mathrm{C}$ & 774631.28 & 328269.36 & 425708.27 & 634859.60 & 317424 & -- & -- \\
\hline $\mathrm{A}(\mathrm{m})$ & 472.26 & 578.61 & 512.18 & 441.09 & 501.16 & -- & -- \\
\hline
\end{tabular}

Co: nugget effect; Co+C: baseline; A: range.

It is observed that the nugget effect presented zero value for all the attributes in the studied layers. Values of nugget effect close to zero were found by Bottega et al. (2013) and Nagahama et al. (2016) who pointed out that the occurrence of such values increases the accuracy of estimates through kriging. This is because the lower the proportion of the nugget effect in relation to the variogram baseline, the greater the continuity of the phenomenon and the variance of the estimate, and the greater the confidence that can be had in the estimation (Bottega et al., 2013).

As for the results obtained for the average RP in the layers there is variation of $422.92 \mathrm{~m}$ and $584.01 \mathrm{~m}$ which shows that the sample mesh could be at least $422.92 \mathrm{~m}$ of horizontal distance since it was used the distance of $45 \mathrm{~m}$; that is, to obtain the same precision of data sampled, the meshes could have been of at least $422.92 \mathrm{~m}$ and maximum of $584.01 \mathrm{~m}$.

It should be noted that the highest reaches were obtained in the $0.10-0.20$ and $0.20-0.30 \mathrm{~m}$ layers, demonstrating continuity of RP in these layers of the profile along the area, probably due to the traffic effect of machines that contributed to the formation of compacted layers in a more comprehensive way by the distribution of the exerted pressures on the surface of the soil (Freddi et al., 2007; Bergamin et al., 2010a; Bottega et al., 2013; Valadão et al., 2015).

In the isolines maps (Figure 1) with the mean and maximum RP values grouped into 6 color classes, we can verify the variability of RP within each layer along the area. It is observed a discrepancy in the maximum values of each layer, which indicates that in many cases, the average masks the results obtained within the study area. Thus, a higher concentration of areas in the map with values above 4,000 $\mathrm{kPa}$ is observed when the maximum value of the layer is used, and this will increase the area to be scarified / subsoiled. And since the aim of precision agriculture is to make the correct management, the use of maximum layer value allows better expression of compaction areas. 
Average layer value

A

B

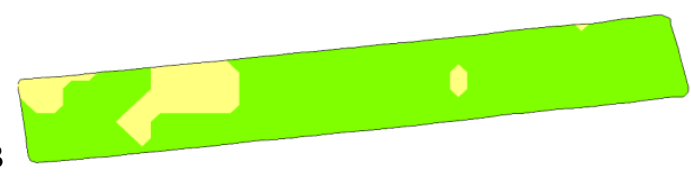

C

$\mathrm{D}$
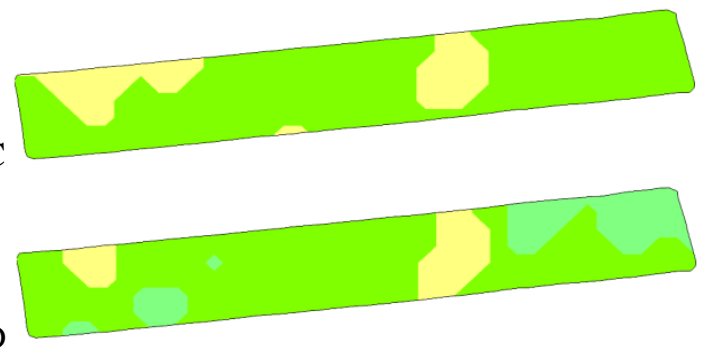

E

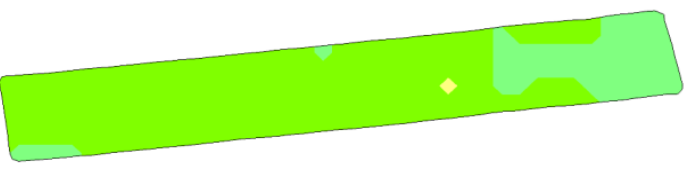

Maximum Layer Value

A

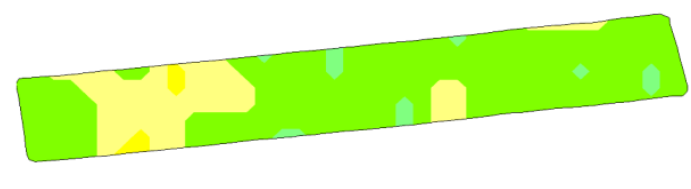

B

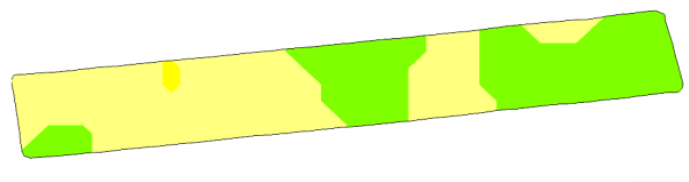

$\mathrm{C}$

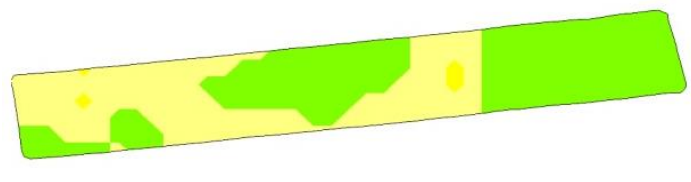

D

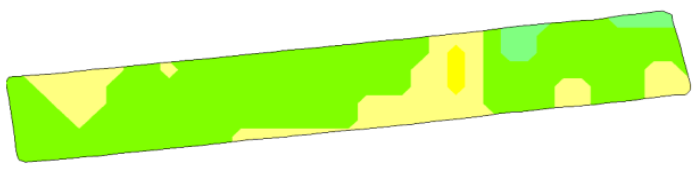

E

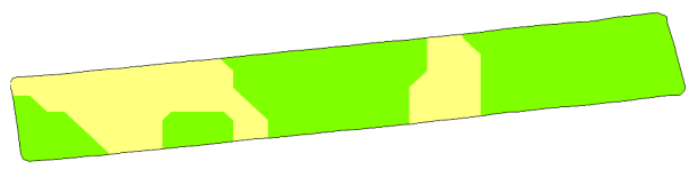

Below 2,000.00

2,000.00-3,000.00

3,000.00-4,000.00

4,000.00-5,000.00

5,000.00-6,000.00

Above 6,000.00

FIGURE 1. Penetration resistance (RP) maps using the average value of the layer and the maximum value. A - $0.00-0.10 \mathrm{~m}$. $\mathrm{B}=0.10-0.20 \mathrm{~m} . \mathrm{C}=0.20-0.30 \mathrm{~m} ; \mathrm{D}=0.30-0.40 \mathrm{~m} ; \mathrm{E}-0.00-0.40 \mathrm{~m}$.

The evaluation based on the mean values of RP in the layers can lead to erroneous results regarding soil management procedures in the studied area. In this case, it overestimates the area with intermediate RP regions (2.00$3.00 \mathrm{MPa}$ ) which may compromise crop yield, since, according to Secco et al. (2009), corn suffers reduction of production when RP values are close to $3 \mathrm{MPa}$.
In the evaluated profiles it was observed that up to $0.30 \mathrm{~m}$ depth occurred critical RP levels (Figure 2), and in a punctual way up to the depth of $0.40 \mathrm{~m}$, which indicates that there will be difficulty in root growth in the profile, mainly in corn crop as observed by Freddi et al. (2007), Bergamin et al. (2010a) and Bergamin et al. (2010b); since most of the area presented RP values close to $3 \mathrm{MPa}$. 

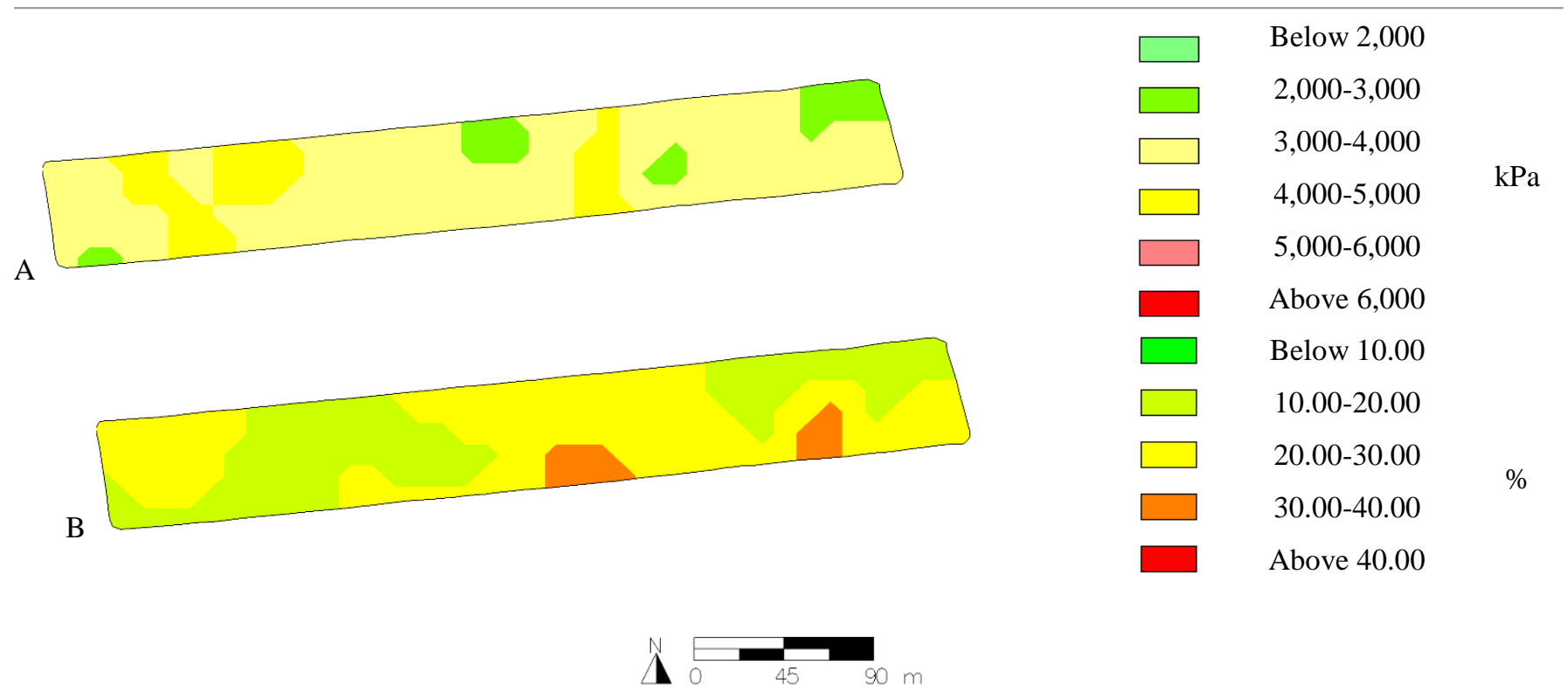

FIGURE 2. Maximum profile resistance $(A)$ and depth $(\mathrm{cm})$ of the maximum resistance in the soil profile (B).

Starting from the premise that a differentiated management must be carried out within the study area when analyzing Table 5 it is verified that in the layer $0.00-0.10 \mathrm{~m}$ high percentage of the occupied area $(<2000 \mathrm{kPa})$, that is, in this first layer, the compaction level is low, but when using the maximum RP there is a displacement of the values, indicating that most of the area in the $0-0.10 \mathrm{~m}$ layer presents intermediate values of maximum RP $(2,000-3,000$ $\mathrm{kPa})$, followed by critical RP values $(3,000-4,000 \mathrm{kPa})$. The other layers presented most part of the area at intermediate RP levels (2,000-3,000 kPa), mainly in the layers $0.10-0.20$ $\mathrm{m}, 0.20-0.30$ and $0.30-0.40 \mathrm{~m}$; the same occurred with maximum RP, except in the layer $0.10-0.20 \mathrm{~m}$ which presented higher percentage of value above $3,000 \mathrm{kPa}$.

TABLE 5. Percentage of occupied area in each class of penetration resistance.

\begin{tabular}{|c|c|c|c|c|c|c|}
\hline \multirow[b]{2}{*}{$\mathrm{RP}(\mathrm{kPa})$} & \multicolumn{6}{|c|}{ Layers (m) } \\
\hline & $0.00-0.10$ & $0.10-0.20$ & $0.20-0.30$ & $0.30-0.40$ & General average & $\mathrm{RP}$ maximum \\
\hline & \multicolumn{6}{|c|}{ Average layer value } \\
\hline$<2,000$ & 97.40 & 0.00 & 0.00 & 18.23 & 21.88 & 0.00 \\
\hline 2,000 to 3,000 & 2.60 & 86.46 & 81.77 & 69.79 & 77.60 & 10.42 \\
\hline 3,000 to 4,000 & 0.00 & 13.54 & 18.23 & 11.98 & 0.52 & 72.92 \\
\hline 4,000 to 5,000 & 0.00 & 0.00 & 0.00 & 0.00 & 0.00 & 16.67 \\
\hline 5,000 to 6,000 & 0.00 & 0.00 & 0.00 & 0.00 & 0.00 & 0.00 \\
\hline \multirow[t]{2}{*}{$>6,000$} & 0.00 & 0.00 & 0.00 & 0.00 & 0.00 & 0.00 \\
\hline & \multicolumn{6}{|c|}{ Maximum Layer Value } \\
\hline$<2,000$ & 4.69 & 0.00 & 0.00 & 4.17 & 0.00 & -- \\
\hline 2,000 to 3,000 & 72.92 & 45.31 & 56.25 & 70.31 & 66.15 & -- \\
\hline 3,000 to 4,000 & 20.31 & 53.65 & 42.19 & 23.96 & 33.85 & -- \\
\hline 4,000 to 5,000 & 2.08 & 1.04 & 1.56 & 1.56 & 0.00 & -- \\
\hline 5,000 to 6,000 & 0.00 & 0.00 & 0.00 & 0.00 & 0.00 & -- \\
\hline$>6,000$ & 0.00 & 0.00 & 0.00 & 0.00 & 0.00 & -- \\
\hline
\end{tabular}

Therefore, greater control over the area and on compacted layers allow to make exact decisions on the management to be adopted, as well as the implement to be used, aiming to reduce ploughing and avoiding possible compaction. However, in spite of being reported in researches that soybean does not suffer reduction on productivity in no tillage system with critical RP values on surface (Marasca et al., 2011; Valadão et al., 2015), that is, ranging from 3.0 to 4.0 $\mathrm{MPa}$ it is necessary differentiated management for the removal of the compacted layers, since this condition can restrict the root development of the corn (Freddi et al., 2007; Bergamin et al., 2010a; Bergamin et al., 2010b; Valadão et al., 2015) when doing succession with soybean.
Evaluating the percentage of occupied area by the maximum values of RP (Table 6) we found that in the layer $<10 \mathrm{~cm}$ and $>40 \mathrm{~cm}$, it had $0.0 \%$ occupied, that is, it had no evidence of compaction. However, in the other layers, compaction indexes were obtained, being layer $0.20-0.30 \mathrm{~m}$ comprising maximum RP values in $54.17 \%$ of the area, followed by the layer $0.10-0.20 \mathrm{~m}$ with $39.58 \%$ of the area and, finally, the layer $0.30-0.40 \mathrm{~m}$ with only $6.25 \%$. Therefore, for the maximum RP in $100.00 \%$ of the area it is necessary to use the management in order to decompress the soil in layer $0.10-0.40 \mathrm{~m}$. 
TABLE 6. Percentage of area occupied by maximum RP values in each soil layer.

\begin{tabular}{cc}
\hline Depth of maximum RP & Percentage (\%) \\
\hline$<10 \mathrm{~cm}$ & 0.00 \\
10 to $20 \mathrm{~cm}$ & 39.58 \\
20 to $30 \mathrm{~cm}$ & 54.17 \\
30 to $40 \mathrm{~cm}$ & 6.25 \\
$>40 \mathrm{~cm}$ & 0.00 \\
\hline
\end{tabular}

The results of this study allow the identification and differentiation of regions with critical compaction levels which require localized soil management procedures aiming the decompaction of the soil at the most adequate depth and only where it is really necessary.

\section{CONCLUSIONS}

The soil resistance to penetration presents spatial variability detected by means of the spherical semivariogram in all the evaluated soil layers.

The resistance to penetration present spatial dependence in all layers within the sampling grid with the highest reaches in layers $0.10-0.20$ and $0.20-0.30 \mathrm{~m}$, in which critical levels have been verified, probably due to the continuous traffic of machines / implements.

The adoption of no tillage system and constant traffic of machines favors the appearance of intermediate values of soil resistance to penetration $(2.00-3.00 \mathrm{MPa})$, in most of the area.

In most of the area, soil resistance to maximum penetration is in the layers $0.20-0.30$ and $0.10-0.20 \mathrm{~m}$, respectively.

\section{ACKNOWLEDGEMENTS}

We would like to thank the FUNDECT - Fundação de Apoio ao Desenvolvimento do Ensino, Ciência e Tecnologia from the State of Mato Grosso do Sul, by granting the fourth author a master's scholarship. Also to CAPES - Coordenação de Aperfeiçoamento de Pessoal de Nível Superior by the master's scholarship to the third and fifth author. To the owners of the UFGD our thanks.

\section{REFERENCES}

Albiero D, Maciel AJS, Milan M, Monteiro LA, Mion RL (2012) Avaliação da distribuição de sementes por uma semeadora de anel interno rotativo utilizando média móvel exponencial. Revista Ciência Agronômica 43(1):86-95. DOI: http://dx.doi.org/10.1590/S1806-

66902012000100011

Alves SMF, Queiroz DM, Alcântara GR, Reis EF (2014) Variabilidade espacial de atributos físico-químicos do solo usando técnicas de análise de componentes principais e geoestatística. Bioscience Journal 30(3):22-30.

ASABE - American Society of Agricultural and Biological Engineers (2006) Soil cone penetrometer. ASABE, p902904. (ASABE standard: ASAE S313.3 FEB04).

Bergamin AC, Vitorino ACT, Franchini JC, Souza CMA, Souza FR (2010a) Compactação em um Latossolo Vermelho Distroférrico e suas relações com o crescimento radicular do milho. Revista Brasileira de Ciência do Solo 34(3):681-691. DOI: http://dx.doi.org/10.1590/S010006832010000300009
Bergamin AC, Vitorino ACT, Lempp B, Souza CMA, Souza FR (2010b) Anatomia radicular de milho em solo compactado. Pesquisa agropecuária Brasileira 45(3):299305. DOI: http://dx.doi.org/10.1590/S0100204X2010000300010

Betioli Júnior E, Moreira WH, Tormena CA, Ferreira CJB, Silva AP, Giarola NFB (2012) Intervalo hídrico ótimo e grau de compactação de um Latossolo Vermelho após 30 anos sob plantio direto. Revista Brasileira de Ciência do Solo 36(3):971-982. DOI: http://dx.doi.org/10.1590/S0100-06832012000300027

Bottega EL, Queiroz DM, Pinto FAC, Souza CMA (2013) Variabilidade espacial de atributos do solo em sistema de semeadura direta com rotação de culturas no cerrado brasileiro. Revista Ciência Agronômica 44(1):1-9.

Coelho DS, Cortez JW, Olszevski N (2012) Variabilidade espacial da resistência mecânica à penetração em Vertissolo cultivado com manga no perímetro irrigado de Mandacaru, Juazeiro, Bahia, Brasil. Revista Brasileira de Ciência do Solo 36(3):755-763. DOI:

http://dx.doi.org/10.1590/S0100-06832012000300007

Cortez JW, Olszevski N, Pimenta WA, Patrocínio Filho AP, Souza EB, Nagahama HJ (2014) Avaliação da intensidade de tráfego de tratores em alguns atributos físicos de um Argissolo Amarelo. Revista Brasileira de Ciência do Solo 38(3):1000-1010. DOI: http://dx.doi.org/10.1590/S0100-06832014000300032

Cunha JPR, Cascão VN, Reis EF (2009) Compactação causada pelo tráfego de trator em diferentes manejos de solo de solo de solo de solo Acta Scientiarum. Agronomy 31(3):371-375. DOI:

http://dx.doi.org/10.4025/actasciagron.v31i3.819

Freddi OS, Centurion JF, Beutler NA, Aratani RG, Leonel CL (2007) Compactação do solo no crescimento radicular e produtividade da cultura do milho. Revista Brasileira de Ciência do Solo 31(4):627-636. DOI: http://dx.doi.org/10.1590/S0100-06832007000400003

Guimarães RML, Blainski E, Fidalski J (2013) Intervalo hídrico ótimo para avaliação da degradação física do solo. Revista Brasileira de Ciência do Solo 37(6):1512-1521. DOI: http://dx.doi.org/10.1590/S010006832013000600008

Marasca I, Oliveira CAA, Guimarães EC, Cunha JPAR, Assis RL, Perin A, Menezes LAS (2011) Variabilidade espacial da resistência do solo à penetração e teor de agua em sistema de plantio direto na cultura da soja. Bioscience Journal 27(2):239-246. 
Melo RP, Albiero D, Monteiro LA, Souza FH, Silva JG (2013) Qualidade na distribuição de sementes de milho em semeadoras em um solo cearense. Revista Ciência Agronômica 44(1):94-101. DOI: http://dx.doi.org/10.1590/S1806-66902013000100012

Molin JP, Dias CTS, Carbonera L (2012) Estudos com penetrometria: Novos equipamentos e amostragem correta Revista Brasileira de Engenharia Agrícola e Ambiental 16(5):584-590.

Nagahama HJ, Cortez JW, Pimenta WA, Pereira Filho AP, Souza EB (2016) Resistência do solo à penetração em sistemas de preparo e velocidades de deslocamento do trator. Comunicata Scientiae 7(1):56-65.

Nogueira MCS (2007) Experimentação agronômica $I$. Piracicaba, Universidade de São Paulo, 479p.

Oliveira Filho FX, Miranda NO, Medeiros JF, Silva PCM, Mesquita FO, Costa TKG (2015) Zona de manejo para preparo do solo na cultura da cana-de-açúcar. Revista Brasileira de Engenharia Agrícola e Ambiental 19(2):186193. DOI: http://dx.doi.org/10.1590/18071929/agriambi.v19n2p186-193

Oliveira IA, Campos MCC, Soares MPR, Aquino RE, Marques Júnior J, Nascimento EP (2013) Variabilidade espacial de atributos físicos em um Cambissolo Háplico sob diferentes usos na região sul do Amazonas. Revista Brasileira de Ciência do Solo 37(4):1103-1112.
Rosolem CA, Fernandez EM, Andreotti M, Crusciol CAC (1999) Crescimento radicular de plântulas de milho afetado pela resistência do solo à penetração. Pesquisa Agropecuária Brasileira 34(5):821-828. DOI: http://dx.doi.org/10.1590/S0100-204X1999000500013

Secco D, Reinert DJ, Reichert JM, Silva VR (2009) Atributos físicos e rendimento de grãos de trigo, soja e milho em dois Latossolos compactados e escarificados. Ciência Rural 39(1):58-64. DOI: http://dx.doi.org/10.1590/S0103-84782009000100010

Silva RP, Cassia MT, Voltarelli MA, Compagnon AM, Furlani CEAF (2013) Qualidade da colheita mecanizada de feijão em dois sistemas de preparo do solo. Revista Ciência Agronômica 44(1):61-69.

Streck CA, Reinert DJ, Reichert JM, Kaiser DR (2004) Modificações em propriedades físicas com a compactação do solo causada pelo tráfego induzido de um trator em plantio direto. Ciência Rural 34(3):755-760. DOI: http://dx.doi.org/10.1590/S0103-84782004000300016

Valadão FCA, Weber OL, Valadão Júnior DD, Scarpinelli A, Deina FR, Bianchini A (2015) Adubação fosfatada e compactação do solo: sistema radicular da soja e do milho e atributos físicos do solo. Revista Brasileira de Ciência do Solo 39(1):243-255. DOI: http://dx.doi.org/10.1590/01000683rbcs20150144

Vaz CMP, Manieri JM, Maria IC, Tuller M (2011) Modeling and correction of soil penetration resistance for varying soil water content. Geoderma 166(2):92-101. DOI: https://doi.org/10.1016/j.geoderma.2011.07.016 